\title{
Socio-sanitary Aspects and Microbiological Quality of Drinking Water in the Prefecture of Golfe (Togo)
}

\author{
Bouraïma Djeri, PhD \\ Essozimna Kogno, M.Sc. \\ Komlan Bilakema, M.Sc. \\ Messanh Kangni-Dossou, Ing. \\ Kouassi Soncy, M.Sc. \\ Essodolom Taale, PhD \\ Yaovi Ameyapoh, Prof.
}

Laboratory of Microbiology and Quality Control of Foodstuffs, College of

Biological and Food Technology, University of Lomé, Togo

Doi:10.19044/esj.2019.v15n21p268 URL:http://dx.doi.org/10.19044/esj.2019.v15n21p268

\begin{abstract}
Water is essential for life, but its quality is confronted with several problems, including insufficient hygiene and sanitation, which necessitate a contribution to improving the hygienic quality of drinking water. A descriptive study of 129 randomly selected households was carried out in order to get an idea of the health risks associated with drinking water. Water samples (75) were analyzed using the standardized routine methods described by the European Union. These analyzes related to the following germs: total aerobic flora, total coliforms, thermo tolerant coliforms, Escherichia coli, anaerobic sulfite-reducing bacteria and fecal streptococci. The results showed that $43.41 \%$ of households surveyed do not have a source of water at home. Water sources include wells, boreholes, and rainwater. Drinking water storage containers are not covered in $38.89 \%$ of the cases. Of the 60 households that have a water source and a latrine at the same time, 27 households or $45 \%$ have latrines within 15 meters of the water source. The microbiological analyzes showed that the drinking water samples analyzed are contaminated to varying degrees by the germs retained by the European Union criteria. Total germs and coliforms resulted in high levels of non-compliance. The waters of the storage containers were the most contaminated. Appropriate measures shall be taken for the monitoring and disinfection of these waters before their use.
\end{abstract}

Keywords: Drinking water, Health risks, Hygienic quality, Golfe prefecture 


\section{Introduction}

Water as a vital resource and a factor of socioeconomic development affects several areas of human existence and may even be the basis for the organization of certain societies (Bendhia et al., 2006). Water is essential to life, yet a set of factors always reduces its availability and quality. These factors include population growth, inadequate hygiene and sanitation, agricultural production, poverty, poor management of water resources and political unrest. The water needs of the Golfe prefecture population have been increased tenfold with the rapid population growth over the past two decades. The prefecture of Golfe, like the great African cities, is experiencing an uncontrolled urbanization. This situation has allowed the emergence of populated outlying districts. These often populous neighborhoods are set up on sites with lack sanitation, hygiene and social infrastructure as well as water supply network. The supply of water in Togo is provided by the TDE (Togolaise Des Eaux). The extension of the drinking water supply network did not follow the rapid urbanization in Togo and also the high amount to subscribe to TDE is out of most of Togolese revenue. This explains the problems of water supply which are observed in these new districts of the prefecture. The population in response to water shortages used wells or boreholes to access water. While these infrastructures have the advantage of solving the problem of access to water, the quality of this commodity is not often guaranteed. As previously reported by World Health Organization (WHO, 2007; 2011), more than one billion people around the world lack access to improved drinking water systems; an even larger number consume largely contaminated water.

In 2015, a study found that boreholes and wells water in the city of Lomé were contaminated with total mesophilic aerobic flora, total coliforms and fecal streptococci (Soncy et al., 2015). The Golfe prefecture has been affected by water-borne diseases. Indeed in 2013, gastroenteritis was the fifth leading cause of morbidity at $2.10 \%$. In 2012, abdominal pain with a rate of $3.31 \%$ (3889) was the fifth leading cause of intestinal parasitosis with $2.21 \%$ (2595 cases) and diarrhea with 2189 cases were the tenth cause of consultation (District sanitaire de Golfe, 2013). According to the European Union criteria, water intended for consumption and household needs must not contain pathogenic microorganisms, anaerobic sulfite-reducing germs, coliforms and streptococci. All wells water analyzed by Sokegbe et al. (2017) in district $\mathrm{n}^{\circ} 2$ of Lomé were contaminated with Enterococci and $66.67 \%$ of them contained Escherichia coli. These bacteria were also found in the well and boreholes waters of certain districts of Abengourou, Côte d'Ivoire (Aka et al., 2013) and Bamako (Coulibaly, 2005). According to Chippaux et al. (2002), the origin of pollution can be attributed to the defects in sanitation and collection of 
household refuse, to the transfer of pollutants from the surface layers of the soil, to the conditions of drawdown and structure of the structures.

The objective of this work was to study the socio-sanitary and microbiological quality of drinking water in the districts of Sogbossito, Gnamassigan and Zogbégan in the Golfe prefecture with a view to minimize the anthropogenic pollution of water through the supply, transport and storage link.

\section{Materials and methods}

\section{Study area and field data collection}

The study area is located at between 6 $25^{\prime} 01^{\prime \prime} \& 6^{\circ} 26^{\prime} 44^{\prime \prime}$ North latitude and between $1^{\circ} 17^{\prime} 14^{\prime \prime} \& 1^{\circ} 18^{\prime} 48^{\prime \prime}$ East longitude. It is situated in the peripheral area of Lomé in the South of Togo. A cross-sectional, descriptive and analytical study was carried out from July to November 2015 and covered 129 households chosen randomly. In each household, the person in charge of the drinking water supply was surveyed. A total of 129 actors from different localities (Sogbossito: 64, Gnamassigan: 42, Zogbegan: 23) were interviewed. The socio-sanitary conditions were determined using a semi-structured questionnaire and an observation checklist. The questionnaire was addressed to 129 houses. The following data were collected: (i) Socio-demographic data; (ii) Supply drinking water and use; (iii) Hygiene, sanitation, environment and health.

\section{Water sampling}

A total of 75 samples of water samples from various sources of supplying (39 water samples coming from the containers of storage, 10 coming from boreholes and 14 coming from the wells). The material of taking away and transport is consisted of sterile bottles $\left(121^{\circ} \mathrm{C} / 25 \mathrm{mn}\right)$ of $500 \mathrm{ml}$, ice box provided with cooling elements and of a burner to sterilize the taps before taking away. The bucket of each house is used to take water. They were taken in the ice box and quickly taken away (15-20 min) from the laboratory for analysis.

\section{Microbiological analyses}

The microbiological procedures used to analyze water were those recommended in the standardized routine methods adopted in the European Union countries (Directive 98/83 / EC). These analyzes related to the following germs enumeration: total aerobic flora, total coliforms, thermotolerant coliforms, Escherichia coli, anaerobic sulfite-reducing bacteria and fecal streptococci. Microbial enumeration was performed as follows: $1 \mathrm{ml}$ from serial decimal dilutions was used to inoculate Petri dishes incubated in appropriate conditions. Colony count was performed in dishes with between 30 and 300 colonies. Results were expressed as colony forming 
units (CFU / ml). Total aerobic bacteria were determined with Plate Count Agar (PCA) after 48-72 $\mathrm{h}$ incubation at $30^{\circ} \mathrm{C}$. Total coliforms and fecal streptococci were enumerated on Violet Red Bile Lactose (VRBL) and Slanetz Bartley agar after 24-48 h incubation at 30 and $37{ }^{\circ} \mathrm{C}$, respectively. Thermotolerant coliforms and E. coli were determined with violet Red Bile Lactose and Brillance E. coli after $24 \mathrm{~h}$ incubation at $44^{\circ} \mathrm{C}$. The amount of anaerobic sulfite reducing bacteria was assessed by Most Probably Number with Tryptone-Sulfite Neomycin (TSN) agar after $20 \mathrm{~h}$ incubation at $44^{\circ} \mathrm{C}$. The expected results will be: Total aerobic bacteria $\left(30^{\circ} \mathrm{C}\right), 100 / \mathrm{ml}$; Total coliforms $\left(30^{\circ} \mathrm{C}\right), 0 / 100 \mathrm{ml}$; Thermotolerant coliforms $\left(44^{\circ} \mathrm{C}\right), 0 / 100 \mathrm{ml}$; Escherichia coli, 0/250 ml; Fecal streptococci, 0 / 100ml; Anaerobic sulfite reducing bacteria, $2 / 20 \mathrm{ml}$.

\section{Results}

\section{Socio-demographic characteristics of surveyed persons}

The majority of respondents $(58.91 \%)$ lived in a medium standing house and $85.30 \%$ were female. The age of these individuals varied between 16 and 67 years with a majority of individuals in the age groups between 2030 years (42\%) and the average age was 35 years. Of these individuals, $25.58 \%$ had no formal education, $27.91 \%$ had primary education, the majority $(39.53 \%)$ had secondary education and the rest $(6.98 \%)$ had higher education. Most of them were civil servants $(35.66 \%)$, craftsmen $(27.13 \%)$, traders $(25.58 \%)$ and farmers $(11.63 \%)$. The data on the socio-demographic aspect of the respondents is given in Table 1.

Table 1. Socio-demographic characteristics of the respondents

\begin{tabular}{lll}
\hline Variables & Modality & Percentage \% (N=129) \\
\hline Type of habitat & High standing & 11.63 \\
& Medium standing & 58.91 \\
Gender & Low standing & 29.46 \\
Age (years) & Female & 85.30 \\
& Male & 14.70 \\
& $\leq 20$ & 8 \\
& $21-30$ & 42 \\
& $31-40$ & 39 \\
Education level & $41-50$ & 35 \\
& $>51$ & 5 \\
& Not attending school & 25.58 \\
& Primary & 27.91 \\
& Secondary & 39.53 \\
& Superior & 6.98 \\
\hline
\end{tabular}




\begin{tabular}{lll}
\hline Profession & Officials & 35.66 \\
& Craftsmen & 27.13 \\
& Traders & 25.58 \\
& Farmers & 11.63 \\
\hline
\end{tabular}

\section{Health aspects of drinking water supply}

As a result of the survey (Table 2), $43.41 \%$ of households had no source of water. Indeed, the water supply is at a distance of more than 200 meters for $71.43 \%$ of the concessions. Of the 129 households surveyed, $63.57 \%$ got water from the well, $53.49 \%$ from boreholes and $14.73 \%$ collected rainwater. Of the 73 households with a water source, only $43.80 \%$ protected their water source. Seals (45.24\%), jars (32.54\%) and barrels (19.05\%) were used for the storage of drinking water. The majority (48.97\%) washes the storage container at least once a week, but others did so before each filling $(34.13 \%)$. For the mode of washing the storage containers, it was found that $53.97 \%$ washed with water and detergent, $34.92 \%$ with water alone and $11.11 \%$ with chlorinated soap. Most respondents (55.04\%) responded that they never treated water before it was consumed, compared with only $44.96 \%$ of respondents. Indeed, almost all households $(94.83 \%)$ used chlorination as a method of water treatment. The majority of waterborne diseases were due to gastroenteritis $(32.56 \%)$, diarrhea $(27.91 \%)$ and intestinal parasitosis $(22.48 \%)$.

Table 2. Health aspects of water supply

\begin{tabular}{llc}
\hline \multicolumn{1}{c}{ Variables } & Modality & $\begin{array}{c}\text { Percentage \% } \\
(\mathbf{N = 1 2 9})\end{array}$ \\
\hline Availability of water source & Yes & 56.59 \\
supply & No & 43.41 \\
Distance from households to & $\leq 200$ & 28.57 \\
sources of supply & $\geq 200$ & 71.43 \\
Source of supply & Wells & 63.57 \\
& Boreholes & 53.49 \\
Drinking water used in & Rain & 14.73 \\
households & Boreholes & 51.49 \\
& Wells & 57.36 \\
Protection of water sources & Rain & 7.75 \\
& Mineral & 16.28 \\
Transport of water & Yes & 43.80 \\
& No & 56.20 \\
Storage of water & Bowl & 90.70 \\
& Seal & 22.48 \\
& Can & 5.43 \\
& Plastic seal & 45.24 \\
& Jars & 32.54 \\
& Cask & 19.05 \\
& Can & 7.94 \\
& Tank & 4.76 \\
\hline
\end{tabular}




\begin{tabular}{llc}
\hline Protection of drinking water & Yes & 61.11 \\
storage containers & No & 38.89 \\
Washing frequency of storage & Before each filling & 34.13 \\
containers & Once a day & 1.59 \\
& Once a week & 48,41 \\
Duration of storage drinking & Twice a week & 15,87 \\
water & One day & 14.29 \\
Existence of latrines & Two days & 51.59 \\
Type of latrines & $\geq 3$ days & 34.13 \\
& Yes & 69,77 \\
& No & 30,23 \\
Distance from the latrine to the & Septic tank latrine & 54,45 \\
water source & Hand flushing latrine & 11.11 \\
Household waste management & Waterproof pit latrine & 11.11 \\
& Traditional dry latrine & 23.33 \\
Water treatment technology & $\leq 15$ & 45 \\
& Wild dump & 55 \\
& Pre-collection & 81.4 \\
& Chlorination & 18.60 \\
& Decantation & 94.83 \\
Distribution of diseases & Filtration & 5.17 \\
& Alum (Alumina sulphate) & 8.62 \\
& Malaria & 12.07 \\
& Gastroenteritis & 43.41 \\
& Diarrhoea & 32.56 \\
& Parasitoses & 27.91 \\
& Dermatoses & 22.48 \\
& & 3.10 \\
\hline
\end{tabular}

\section{Assessment of microbiological water quality}

The results of the microbiological analyzes showed that the waters were all contaminated by most of the germs wanted. They have been highly contaminated by total aerobic mesophilic flora, total and thermotolerant coliforms as reported by table 3 . Compared to well water, the non-compliance rate was $100 \%$ for total aerobic mesophilic flora, total coliforms and thermotolerant coliforms. Fecal streptococci induced $85.71 \%$ and $57.14 \%$ noncompliance rate for Escherichia coli and anaerobic sulfite-reducing bacteria. 
Table 3. Assessment of the hygienic quality of wells water

\begin{tabular}{|c|c|c|c|c|c|c|}
\hline \multirow[b]{2}{*}{ Germs } & \multicolumn{3}{|c|}{ Number of germs (CFU / ml) } & \multirow[b]{2}{*}{ EU limit } & \multicolumn{2}{|c|}{ Compliance rate $(\%)$} \\
\hline & $\begin{array}{c}\text { Max } \\
\text { value }\end{array}$ & $\begin{array}{l}\text { Min } \\
\text { value }\end{array}$ & $\begin{array}{l}\text { Mean } \\
(\mathrm{n}=21)\end{array}$ & & Compliance & $\begin{array}{l}\text { Non- } \\
\text { complianc } \\
\text { e }\end{array}$ \\
\hline $\begin{array}{l}\text { Total aerobic } \\
\text { mesophilic flora }\end{array}$ & 5400 & 520 & 1880 & 100 & 0 & 100 \\
\hline Total coliforms & 288 & 18 & 100 & 0 & 0 & 100 \\
\hline $\begin{array}{l}\text { Thermotolerant } \\
\text { coliforms }\end{array}$ & 225 & 5 & 69 & 0 & 0 & 100 \\
\hline Escherichia coli & 15 & 0 & 3 & 0 & 42.86 & 57.14 \\
\hline $\begin{array}{l}\text { Anaerobic sulfite- } \\
\text { reducing bacteria }\end{array}$ & 280 & 0 & 42 & 2 & 42.86 & 57.14 \\
\hline Fecal streptococci & 64 & 0 & 12 & 0 & 14.29 & 85.71 \\
\hline
\end{tabular}

Contamination of boreholes water by the total aerobic mesophilic flora resulted in $80 \%$ non-compliance. Total coliforms, thermotolerant coliforms and Escherichia coli respectively induced $40 \%, 40 \%$ and $20 \%$ of samples that did not meet the acceptable limit. Fecal Streptococci were found in $20 \%$ of the boreholes water samples analyzed. The anaerobic sulfite-reducing bacteria germs also induced $20 \%$ non-compliance with water samples (Table 4). Boreholes water was less contaminated.

Table 4. Assessment of the hygienic quality of boreholes water

\begin{tabular}{|c|c|c|c|c|c|c|}
\hline \multirow[b]{2}{*}{ Germs } & \multicolumn{3}{|c|}{ Number of germs (CFU / ml) } & \multirow[b]{2}{*}{ EU limit } & \multicolumn{2}{|c|}{ Compliance rate $(\%)$} \\
\hline & $\begin{array}{c}\text { Max } \\
\text { value }\end{array}$ & $\begin{array}{c}\text { Min } \\
\text { value }\end{array}$ & $\begin{array}{c}\text { Mean } \\
(n=21)\end{array}$ & & Compliance & $\begin{array}{l}\text { Non- } \\
\text { complianc } \\
\text { e }\end{array}$ \\
\hline $\begin{array}{l}\text { Total aerobic } \\
\text { mesophilic flora }\end{array}$ & 21400 & 8 & 8200 & 100 & 20 & 80 \\
\hline Total coliforms & 11 & 0 & 3 & 0 & 60 & 40 \\
\hline $\begin{array}{l}\text { Thermotolerant } \\
\text { coliforms }\end{array}$ & 4 & 0 & 1 & 0 & 60 & 40 \\
\hline Escherichia coli & 1 & 0 & 1 & 0 & 80 & 20 \\
\hline $\begin{array}{l}\text { Anaerobic sulfite- } \\
\text { reducing bacteria }\end{array}$ & 3 & 0 & 1 & 2 & 80 & 20 \\
\hline Fecal streptococci & 2 & 0 & 1 & 0 & 80 & 20 \\
\hline
\end{tabular}

The water collected from the storage containers showed $92.31 \%$ noncompliance with total aerobic mesophilic flora, total coliforms and thermotolerant coliforms. These waters also showed $69.23 \%, 38.46 \%$ and $23.08 \%$ non-conformity, respectively, compared to fecal streptococci, Escherichia coli and anaerobic sulfite-reducing bacteria (Table 5). 
Table 5. Assessment of hygienic quality of water taken from household storage containers

\begin{tabular}{lccccccc}
\hline \multirow{2}{*}{ Germs } & \multicolumn{2}{c}{ Number of germs $(\mathbf{C F U} / \mathbf{m l})$} & & \multicolumn{2}{c}{ Compliance rate (\%) } \\
\cline { 2 - 3 } & $\begin{array}{c}\text { Max } \\
\text { value }\end{array}$ & $\begin{array}{c}\text { Min } \\
\text { value }\end{array}$ & $\begin{array}{c}\text { Mean } \\
(\mathbf{n = 2 1})\end{array}$ & EU limit & & Compliance & $\begin{array}{c}\text { Non- } \\
\text { compliance }\end{array}$ \\
\hline $\begin{array}{l}\text { Total aerobic } \\
\text { mesophilic flora }\end{array}$ & 60000 & 19 & 16300 & 100 & 7.69 & 92.31 \\
$\begin{array}{l}\text { Total coliforms } \\
\text { Thermotolerant }\end{array}$ & 1480 & 0 & 350 & 0 & 7.69 & 92.31 \\
coliforms & 930 & 0 & 200 & 0 & 7.69 & 92.31 \\
$\begin{array}{l}\text { Escherichia coli } \\
\text { Anaerobic sulfite- }\end{array}$ & 6 & 0 & 2 & 0 & 61.54 & 38.46 \\
reducing bacteria & 12 & 0 & 2 & 2 & 76.92 & 23.08 \\
Fecal streptococci & 33 & 0 & 5 & 0 & 30.77 & 69.23 \\
\hline
\end{tabular}

\section{Discussion}

The female sex was more represented among the respondents $(85.30 \%)$. This is because the problem of water supply generally concerns women. Most of the men met come from households to one person and single. Respondents with secondary education were the most represented $(39.53 \%)$, followed by primary (27.91\%) and non-educated $(25.58 \%)$. This rate could be explained by the high percentage of females who at national level are less literate than males (MPDAT, 2015). The high illiteracy rate in the study area may favor behaviors that will compromise the hygienic quality of drinking water.

Of the 129 households, 56 (43.41\%) of households have no water supply. This could be justified by the fact that in Sogbossito and Zogbégan the soil is ferruginous with a deep water table which makes the cost of building a well or borehole high. The water supply is more than 200 meters from the concessions in $71.43 \%$ of the cases for an average time greater than or equal to 15 minutes $(23.21 \%)$. These results are similar to those found by Nassartebaye (2011) in the Gamkallé district of commune IV in Niamey (Niger) where water supply is more than 200 meters from concessions in $30 \%$ of cases.

The results of the microbiological analyzes showed that water samples from storage containers, wells and boreholes were all heavily contaminated by total mesophilic aerobic flora. The presence of this flora would prove the exposure of water to global pollution. It provides information on both indigenous flora and flora brought by pollution (Kimassoum et al., 2011). The samples tested were highly contaminated by total coliforms except for boreholes waters that were moderately contaminated with $40 \%$ noncompliance. The presence of these germs would prove the vulnerability of water to pollution, insufficient water treatment, an unsanitary environment due to hygiene practices around water and water points in general. These unhealthy practices would include the non-protection of water sources and water storage 
containers and insufficient washing of storage containers. The low level of total coliform contamination of boreholes water compared to wells water and storage containers is due to the fact that the drillings are small in diameter and often protected. As for fecal germs, our results showed that samples are contaminated to varying degrees. Water collected in household storage containers and well water revealed high contamination compared to thermotolerant coliforms (100\% non-compliance for well water and $92.31 \%$ for household water). Lacroix (2008) showed in one study that wells water in the old neighborhoods of Sokodé had high concentrations of thermotolerant coliforms. This contamination has been linked to the geological features of Sokodé soil which contribute to making the aquifer extremely vulnerable to pollution sources and aggravated by unhealthy behaviors at the wells (Lacroix, 2008). But in the case of our study this could be true for the district of Gnamassigan where the tablecloth is flush with a clay-sandy soil. For the Sogbossito and Zogbegan neighborhoods, it is more the unhealthy practices and behaviors that would contribute to the water pollution of wells and boreholes because the water table is deep with a ferruginous soil that has a great adsorbent power and often waterproof (MUHT, 2015). Similar observations were reported by Sokegbe et al. (2017) in Lomé, Kiptum and Ndambuki (2012) in Langas, where thermotolerant coliforms were found in all waters analyzes. The presence of germs indicating fecal contamination in the analyzed waters exposes consumers to the risk of waterborne diseases. The samples analyzed were contaminated with fecal streptococci, with high noncompliance rates for well water and household storage tank waters of $85.71 \%$ and $69.23 \%$, respectively. Boreholes water was poorly contaminated $(20 \%)$. The analyzed waters were moderately contaminated with Escherichia coli. The presence of fecal streptococci and Escherichia coli in the analyzed samples indicates contamination of water by animal and human feces. The presence of Escherichia coli in these waters indicates recent fecal contamination. The bacteriological quality of well water in Benin reveals a fecal contamination of the water table especially by Escherichia coli (Degbey et al., 2010). In Abengourou, Aka et al. (2013) counted in $28 \%$ of the analyzed well water strains of Escherichia coli. According to Bricha et al. (2007), sewage systems, septic tanks, plant wastewater and solid waste would be the main sources of groundwater pollution in the urban areas. Anaerobic sulfitereducing bacteria induced $57.14 \%$ non-conformity for well water, while EU standards tolerate 2 germs in $20 \mathrm{ml}$ of a water sample for human consumption. Degbey et al. (2010) reported $96.70 \%$ non-compliance for well water analyzed in Benin. The presence of anaerobic sulfite-reducing bacteria in natural water suggests a fecal contamination and, in the absence of coliform bacteria, an old contamination (Kimassoum et al., 2011). 
In general, samples taken from households drinking water storage containers were more charged with microorganisms than those taken from sources of supply (wells and boreholes) except in a household. This household unlike the others used the chlorine tablets paid in pharmacy and respected the dose of treatment. Tampo et al (2014) propose chlorination adapted to the composition of the well and borehole waters of Lomé to make them drinkable in order to compensate for the inadequacy of the water supply network and to reduce the risks of water-borne diseases. This difference in bacterial load confirms the hypothesis according to which drinking water is further contaminated during the extraction, transport and especially storage. However, for well water, our results have shown that there is contamination at the source. The contamination of the wells depends on the soil permeability, the depth of the water table, the absence or inadequacy of the sanitation structures, the mismanagement of the waste and the method of water collection (Coulibaly, 2005; Degbey et al., 2010). Hygiene measures around water points and water in general could significantly reduce this contamination.

\section{Conclusion}

This study permits to evaluate the social and health status of the households in Sogbossito, Gnamassigan, Zogbégan and the hygienic quality of the drinking water of these households. The socio-sanitary study carried out showed a difficulty in access to household drinking water, lack of sanitation and poor practices during the supply, transport and storage of water. The assessment of the hygienic quality of drinking water showed contamination to varying degrees by the germs retained by the criteria. Thus well, boreholes and storage containers water are mostly contaminated by the total mesophilic aerobic flora and germs due to breaches of hygiene rules. Moreover, the contamination of these waters by these bacteria constitutes a major risk of gastroenteritis for consumers. In general, samples taken from household drinking-water storage containers were more contaminated than those taken from others sources of supply. Compliance with hygiene rules and treatment of water by the populations of the study area should be encouraged to avoid the occurrence of waterborne diseases.

\section{References:}

1. Aka, N., Bamba, S.B., Soro, G., \& Soro, N. (2013). Etude hydro chimique et microbiologique des nappes d'altérites sous climat tropical humide: Cas du département d'Abengourou (Sud-Est de la Cote d'Ivoire). Larhyss Journal, 16, 31-52

2. Bendhia, H., \& Bouri, S. (2006). Contrôle de Qualité des eaux Minérales Conditionnées et Embouteillées. Association Africaine de Microbiologie et d'Hygiène Alimentaire, Numéro spécial, 17-25. 
3. Bricha, S., Ounine, K., Oulkheir, S., El Haloui, N., \& Attarassi, B. (2007). Étude de la qualité physico-chimique et bactériologique de la nappe phréatique de M'nasra, Maroc. Afrique Science, 03(3), 391-404.

4. Chippaux, J.P., Houssier, S., Gross, P., Bouvier, C., \& Brissaud, F. (2002). Étude de la pollution de l'eau souterraine de la ville de Niamey, Niger. Bulletin de la Société de Pathologie Exotique, 94(2), 119-123.

5. Coulibaly, K. (2005). Étude de la qualité physico-chimique et bactériologique de l'eau de puits de certains quartiers du district de Bamako. Thèse de Doctorat en Pharmacie, Faculté de Médecine de Pharmacie et d'Odonto-Stomatologie, Université de Bamako, 69p.

6. Cyriaque, D., Makoutode, M., Fayomi, B., \& De Brouwer, C. (2009). La qualité de l'eau de boisson en milieu professionnel à Godomey au Benin. Afrique Science, 1, 21-22.

7. Degbey, C., Makoutode, M., \& de Brouwer, C. (2010). La qualité de l'eau de boisson en milieu professionnel à Godomey en 2009 au Bénin Afrique de l'Ouest. Journal International de Santé au Travail 2010, 1, $15-22$.

8. District Sanitaire du Golfe / Ministère de la Santé-Togo. (2013). Rapports annuels des activités sanitaires 2012-2013, 478p.

9. Kimassoum, D., Tidjani, A., Doutoum, A.A., Ameyapoh, Y., Soncy, K., Dossou, K., Anani, K., \& de Souza C. (2011). Évaluation de la qualité hygiénique de l'eau de robinet produite par la Société Togolaise des Eaux (TdE) : cas de neuf quartiers de la Commune de Lomé (Togo). Association Africaine de Microbiologie et d'Hygiène Alimentaire, 23 (68), 51-54

10. Kiptum, C.K., \& Ndambuki, J.M. (2012). Well water contamination by pit latrines: A case study of Langas. International Journal of water Resources and Environmental Engineering, 4(2), 35-43.

11. Lacroix, E. (2008). Evaluation de la contamination bactériologique des eaux de puits dans la ville de Sokodé. Rapport de stage, Sokodé (Togo), École Polytechnique de Lausanne, Section Sciences et Technologies de l'eau, 94p.

12. MPDAT (Ministère de la Planification, du Développement et de l'Aménagement du Territoire) (2015). Troisième Enquête Démographique et de Santé au Togo (EDST-III, 2013-2014). Rapport de synthèse, $19 \mathrm{p}$.

13. MUHT (Ministère de l'Urbanisme et de l'Habitat-Togo) (2015). Elaboration du Schéma directeur d'aménagement et d'urbanisme du Grand Lomé. Rapport Diagnostic, 307p.

14. Nassartebaye, N. (2011). Accès à l'eau potable et à l'assainissement : quels enjeux pour la santé dans les quartiers précaires? Etude appliquée au quartier Gamkallé de la commune IV de Niamey. Mémoire de 
maitrise en géographie, Université Abdou Moumouni de Niamey, Niger, 90p.

15. Pommepuy, M., Guillaud, J.F., Dupray, E., Derrien, A., Guyader, F., \& Cormier, M. (1992). Enteric bacteria survival factors, Water Science and Technology, 25(12), 93-103.

16. Sokegbe, O., Djeri B., Kogno E., Kangni-Dossou M., Mensah R., Soncy K. \& Ameyapoh Y. (2017). Les Risques sanitaires liés aux sources d'eau de boisson dans le district no2 de Lomé-Commune : Cas du quartier d'Adakpamè. International Journal of Biological and Chemical Sciences 11(5): 2341-2351

17. Soncy, K., Djeri, B., Anani, K., Eklou-Lawson, M., Adjrah, Y., Karou, D.S., Ameyapoh, Y. \& de Souza C. (2015). Evaluation de la qualité bactériologique des eaux de puits et de forage à Lomé, Togo. Journal of Applied Biosciences, 91, 8464-8469.

18. Tampo, L., Ayah, M., Kodom, T., Tchakala, I., Boguido, P., Bawa, L.M., \& Djanéyé-Bouindjou, G. (2014). Impact de la demande en chlore et de la chloration sur la désinfection des eaux de puits des quartiers de Lomé : cas des quartiers de Démakpoé et d'Agbalépédogan (Togo). Journal of Applied Biosciences, 75, 62726281.

19. WHO (World Health Organization) (2007). Combattre les maladies véhiculées par l'eau à la maison, Rapport, 36p. Available on : http://www.who.int/water_sanitation_health/publications/waterborne _disease/fr/

20. WHO (World Health Organization) (2011). Guidelines for drinkingwater quality. Four Edition, Volume1, Geneva, 564p. 